\title{
Study of the stress of parents of patients with cleft lip and palate in a surgical process
}

\author{
Estudo do estresse de pais de pacientes com fissura \\ labiopalatina em processo cirúrgico
}

\author{
Maria de Lourdes Merighi TABAQUIM ${ }^{1}$ \\ Matilde Aparecida Motta MARQUESINI²
}

\begin{abstract}
Family with children affected by genetic factors or teratogenics involving functional, aesthetic and psychological sequels such as cleft lip and palate are vulnerable to several stress levels and need corrective and rehabilitation interventions. This study aimed to investigate the stress levels of fathers and mothers before and after surgical intervention in children with cleft lip and palate. The participants were 14 parents of children diagnosed with Cleft Incisive Transforamen Unilateral and Bilateral Incisive Transforamen of both genders, 21-53 participants of the surgical intervention program at the Hospital de Reabilitação de Anomalias Craniofaciais, Universidade de São Paulo in the city of Bauru, State of São Paulo. The results have allowed us to conclude that the people responsible for patients, patients and parents of the patients with cleft palatal lip, in surgical situation, present higher levels of stress in the period of pre-surgery, with modified quality in the autonomic aspects of the organism, besides bodily significantly unsatisfactory reactions.
\end{abstract}

Uniterms: Cleft palate; Surgery, plastic; Stress, psychological; Stress, physiological.

\section{Resumo}

Familias com filhos afetados por fatores genéticos ou teratogênicos envolvendo sequelas estruturais, funcionais, estéticas e psicológicas, como nas fissuras labiopalatinas, são vulneráveis a diferentes graus estressores. Este estudo teve por objetivo investigar o nível de estresse de pais e mães antes e após a intervenção cirúrgica de filhos com fissura labiopalatina. Participaram 14 pais de crianças com Fissura Transforame Incisivo Uni e Bilateral, de ambos os sexos, na faixa etária de 21 a 53 anos, integrantes do programa de intervenção cirúrgica do Hospital de Reabilitação de Anomalias Craniofaciais da Universidade de São Paulo. Foram utilizados os instrumentos: 1) de Identificação; 2) Questionário de Ansiedade; 3) Questionário da Imagem Corporal; e 4) Reconhecimento dos sinais de estresse. Os resultados permitiram concluir que os sujeitos, pais e responsáveis dos pacientes com fissura labiopalatina, em situação cirúrgica, mostraram níveis mais elevados de estresse no período de pré-cirurgia, com qualidade alterada dos aspectos autonômicos do organismo, além de reações corporais significativamente insatisfatórias.

Unitermos: Fissura palatina; Cirurgia plástica; Estresse psicológico; Estresse fisiológico.

There are several ways to express feelings. One is based on emotions, the most universal ones being happiness, sadness, anger, fear and disgust (Le Doux, 2001; Koenigs et al., 2007). When fear takes place for a

$\nabla \nabla \nabla \nabla$

1 Universidade de São Paulo, Faculdade de Odontologia de Bauru, Departamento de Fonoaudiologia. Alameda Octávio Pinheiro Brizola, 9-75, 17012-901, Bauru, SP, Brasil. Correspondência para/Correspondence to: M.L.M.TABAQUIM. E-mail: <ptabaqui@uol.com.br>.

2 Universidade de São Paulo, Hospital de Reabilitação de Anomalias Craniofaciais. Bauru, SP, Brasil. 
long time, the feeling turns into a state of tension or stress, and is manifested in an emotion called anxiety. Fear can become chronic, so the individual develops an sensation of future danger or threat, and this kind of fear can result in anxiety and stress (Gazzaniga, Ivry \& Mangun, 2006).

In anxiety and stress physiological adaptations go beyond the scope of the autonomic nervous system and affect the endocrine and immune systems. Stress means aggression to the organism in its entirety, and it can be life threatening, for situations of any kind, such as cold, traumatic shock, surgical intervention etc.

Stress is a normal mechanism and, if well understood and controlled, is beneficial to man, as it causes humans to react in situations of risk. However, the lack of control and chronicity, cause the constant pressure in to result losses, both intellectually and physically. The stimulus that could be beneficial is replaced by fatigue and may lead to the susceptibility to both physical and mental illnesses.

A circumstance that triggers or exponentially increases stress for a family occurs as a result of genetic or teratogenic factors, causing in children structural, functional aesthetic and psychological problems. Moraes, Buffa and Motti (2009) claim that the influence of parents first impact facing the child's lip and/or palate fissure is usually quite strong, profound and frequently long-lasting. On the other hand, the duration and intensity of emotional reactions relate to the attitude of parents toward problem. The more visible those defects are, the more immediate and intense these emotional reactions and concerns will be. This impact can be minimized if soon after birth, parents receive proper guidance and explanation, which decreases cognitive evaluations of damage or threat and intense stress reactions.
According Lofiego (1992), cleft lip and palate is a congenital malformation that occurs in different embryological periods and results in a series of sequels that can accompany the individual throughout life. They are characterized by the lack of continuity between the structures of the lip and they can be segmental or even cover the entire mid-face. In addition to the cleft upper lip, there are those, more rare, affecting from the lower lip to the mandibular arch. These deformities bring major psychological disorders and when skillfully approached with creativity and opportunity, become a small scar or a half past memory (Silva Filho, Valladares Neto, Capelozza Filho \& Freitas, 2003; Spina, Psillakis \& Lapa, 1972).

The morphological change is clinically variable and it may involve the lip, palate or both. They can be classified as described in Table 1.

The medical-surgical procedure causes psychological and emotional stress in most people, even those with a certain standard of balance and stability. When, in the the family situation, parents have already experienced the conditions of surgical risk of a child, the stress levels become elevated and leaves parents, in general, in a state of alarm (Troíjo, 2001).

Constant hospitalizations may cause stress, fear, anxiety, morbid fantasies, and give space to feelings of helplessness and weakness for the patient and his family. Some studies (Benevides-Pereira, 2002; Carraro, 2001; Coluchi, 2002; Pereira, 1999; Ribeiro, Tavano \& Neme, 2002; Ruiz, 2007; Salina, 1999; Silva, 2003; Troíjo, 2001) have examined the emotional reactions of parents accompanying patients with cleft palate and other craniofacial malformations, waiting for the completion of corrective surgeries of different complexities. The studies identified the presence of negative feelings as a result of the states of anxiety and

\section{Table 1}

Classification and description of the types of cleft palate (Spina et al., 1972)

\begin{tabular}{ll}
\hline Type & Descriptions \\
\hline Pre-foramen fissure & Cleft lips, bilateral and median. \\
Post-foramen fissure & Cleft palates, generally median, may lie only in the uvula, soft palate or involve the hard palate. \\
Cleft lip and palate & Unilateral, bilateral, up to the lip, the alveolar arch and palate, involving anatomical structures \\
& derived from primary and secondary palates. \\
Rare facial clefts & Oblique cleft lip, nose and whole face. \\
\hline
\end{tabular}


fear, but with positive expectations regarding the surgical outcome. The social support network was identified as a necessary resource for coping with the stressful situation, essential in the understanding of related information, in addition to the efforts directed to solution of psychological problems and/or control of emotions and feelings, and even religious beliefs, where faith allows confidence in the deity and medical efficiency. Studies revealed the main features of families' functionality related to satisfactory level of communication between parents and their children, the constant performance of parental roles during this process and the satisfactory personal conditions to deal with stress, favoring the welfare of the child.

Considering the important role of parents in this process, this study aimed to investigate the level of stress of fathers and mothers before and after surgery in children with cleft palate.

\section{Method}

This is a descriptive cross-sectional cohort quantitative research. The participants were 14 parents of children diagnosed with Cleft Incisive Transforamen Unilateral and Bilateral Incisive Transforamen of both genders, aged 21-53 years participating in the program in surgery at the Hospital for Rehabilitation of Craniofacial Anomalies in Bauru (SP).

Three instruments were used to assess, anxiety states, body image and stress levels.

- Anxiety Questionnaire (Lipp, 1998). It consists of 14 statements with scalar alternatives (Likert) 1-5 (never to very often), on behavioral and physiological responses, felt at the time. The classification criterion was related to low, medium and high levels.

- Body Image Questionnaire (Motta, 2003). It investigates 6 aspects of body representation: physical condition, body skills, health, appearance, body appreciation and desire for body modification. It includes 4 questions of scalar alternatives (Likert) 0-5 (never to always), 1 involving choices and 1 to be completed. The classification criterion was related to levels low, medium and high.

- Questionnaire for recognition of the signs of stress (Lipp, 1998). It is comprised of 32 behavioral and physiological symptoms, identified as signs of stress.
After the ethical procedures for research with human beings, individual interviews with each one of the responsible for the patient from the hospital institution were scheduled and conducted after being sent by the sector of Nursing and Recreation.

The results of the statistical indicators were presented by means of graphs involving the frequency distribution and descriptive measures (Figures 1-3).

\section{Results}

\section{Characterization of the population}

The age range of the 14 participants in the study varied from 21 years to 53 years. Regarding gender, $85.7 \%$ were female and $14.3 \%$ male. From this feminine universe, we found that $75.0 \%$ were mothers, and the other family relationships were aunt, sister and wife.

We observed that the education levels were between the $4^{\text {th }}$ grade of elementary school and university education, that is, $35.7 \%$ with a college degree, $35.7 \%$ with a high school degree, and $14.3 \%$ with elementary school level (completed $4^{\text {th }}$ grade), $7.1 \%$ of elementary school level up to 6th grade and $7.1 \%$ up to $8^{\text {th }}$ grade.

As for professional activities, 28.6\% were individuals without a profession considered housewives; teachers, seamstresses and households

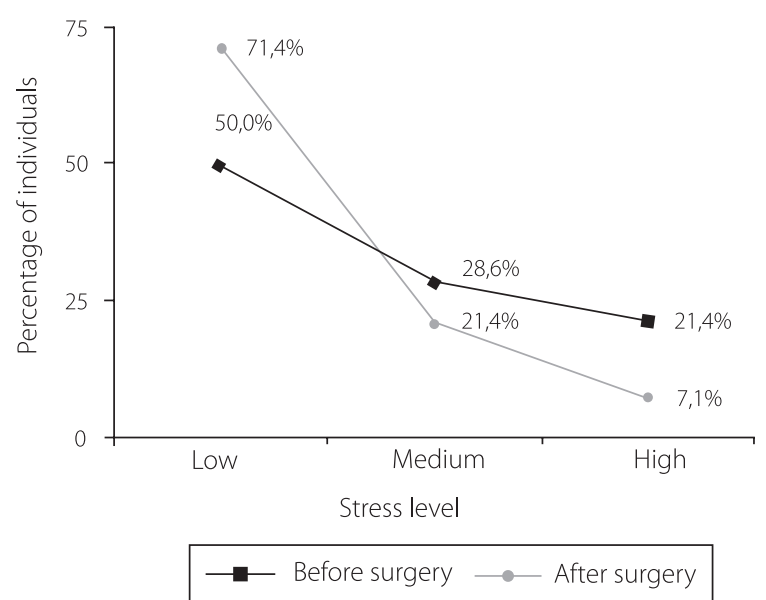

Figure 1. Stress level observed in the group in the conditions of pre-surgery and post-surgery after application of the Anxiety Questionnaire. 
added to the percentage of $14.3 \%$ each one, and other professions, such as pharmacists, geographers, federal civil servants and dental prosthesis technicians represented $7.1 \%$ of the sample each one.
The predominant religion of the participants was Roman Catholic with $57.1 \%, 21.4 \%$ were spiritualists, $14.3 \%$ were christians and $7.1 \%$ said they did not have any religion.

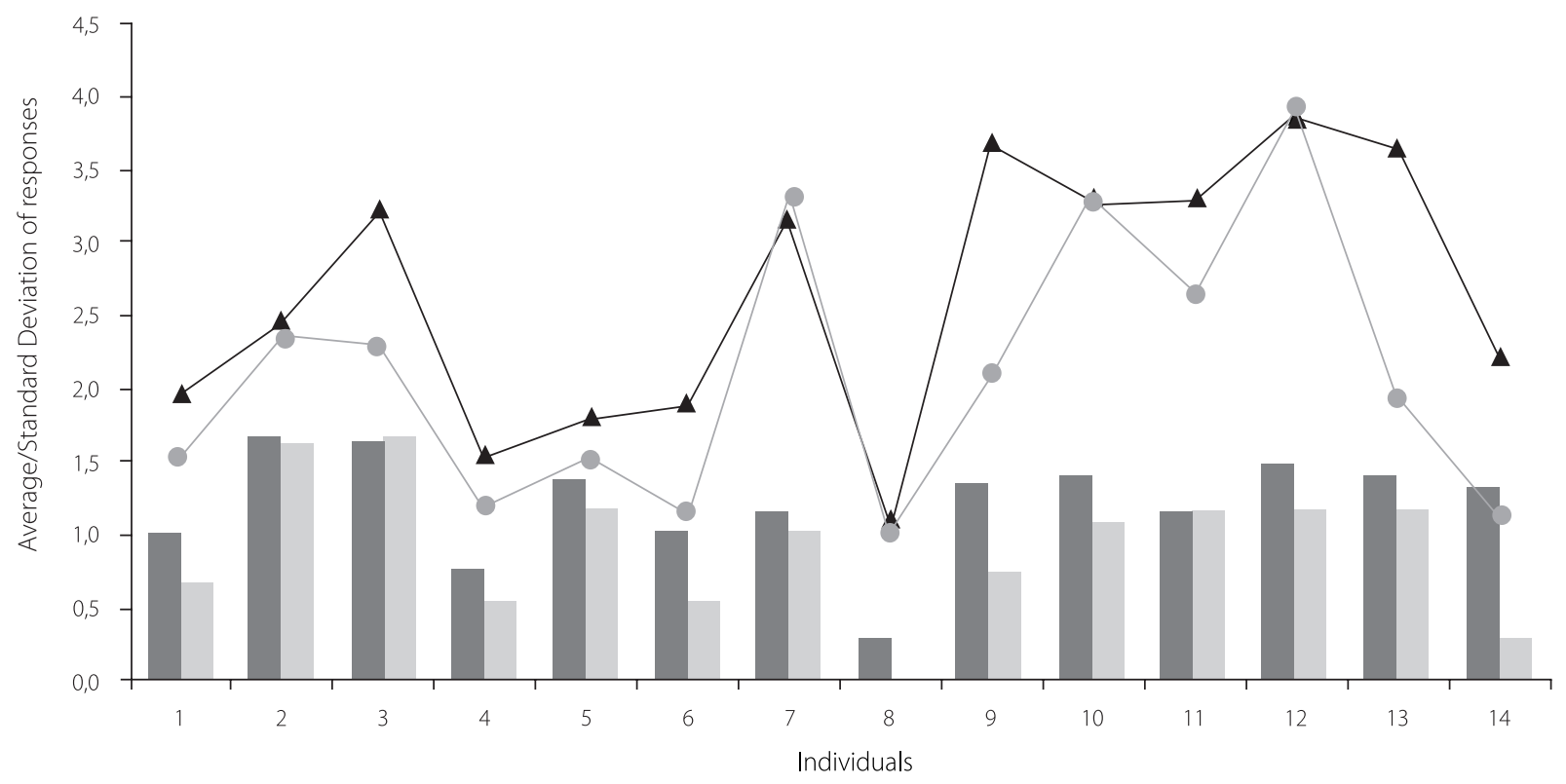

Figure 2. Average and Standard Deviation of the level of stress in the subject pre-and post-surgery.

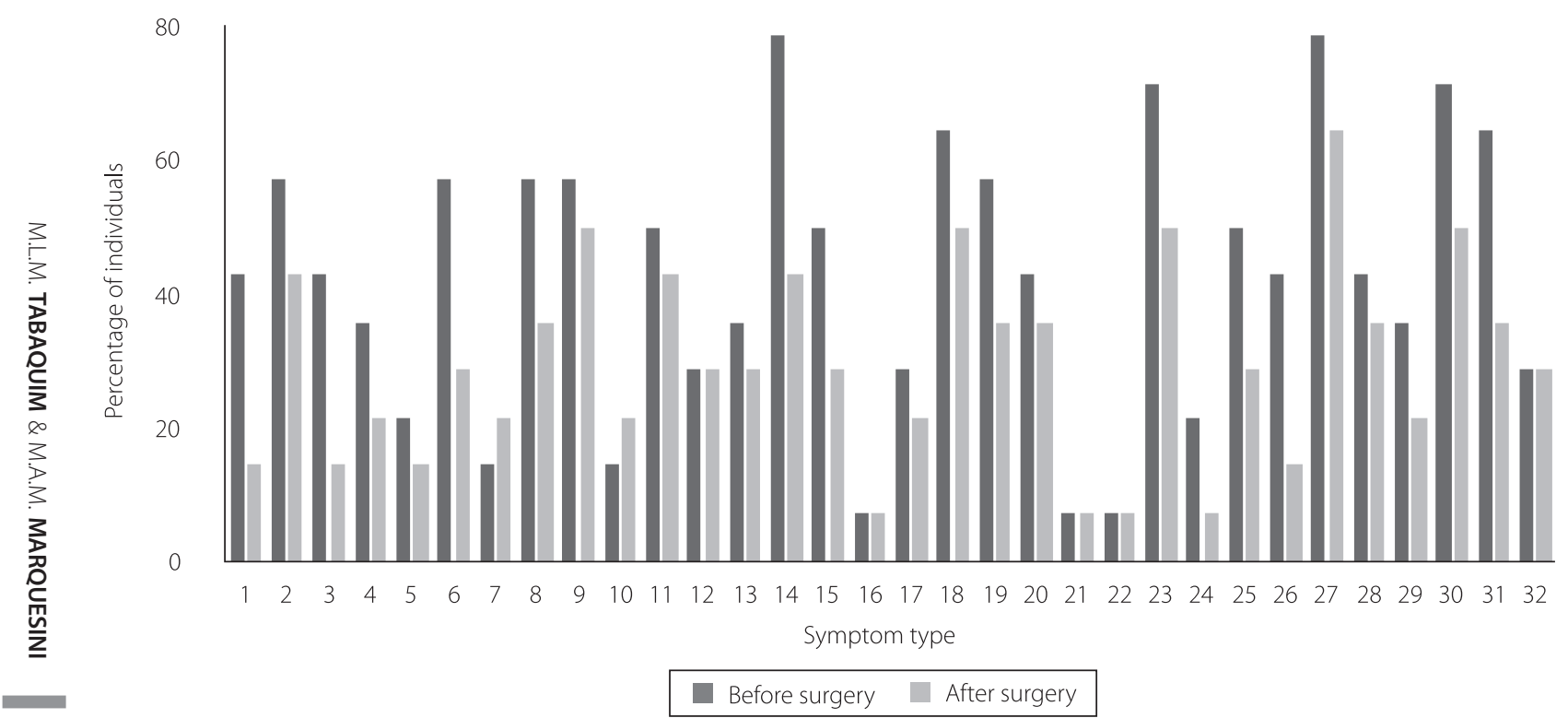

Figure 3. Neurophysiological symptoms related to stress in pre-and post-surgery. 
As for the question about whether they were doing some healthcare treatment, $78.6 \%$ reported undergoing no regular treatment, and $21.4 \%$ pointed to medical treatment of hypertension or adoption of preventive measures.

The marital status of the participants predominated with $57.1 \%$ married, $14.3 \%$ divorced, $14.3 \%$ living together, $7.1 \%$ single, and $7.1 \%$ widowed.

When we asked about the degree of kinship with the person with cleft lip and palate subjected to the surgeries, $7.1 \%$ said they were the patient's wife, $64.3 \%$ were the mother, $14.3 \%$ were the patient's father, $7.1 \%$ were the patient's aunt and $7.1 \%$ were the patient's sister.

The age of the patients who underwent surgery was related to the age group between 6 months old to 44 years old. We found that $50.0 \%$ were from zero to six years old, 21.4\% were aged from 19 to 39 years, 14.3\% between 12 and 18 years, and $7.1 \%$ between 7 and 11 years.

\section{Characterization of the stressors}

When investigating anxiety levels of the participants in the pre-surgical situation of their relative (son, wife, mother, father, aunt and sister), we found that $21.4 \%$ had high levels of stress, $28.6 \%$ medium and $50.0 \%$ low.

In post-operative conditions, $7.1 \%$ had high levels of stress, $21.4 \%$ medium and $71.4 \%$ had low levels of stress.

Comparatively we found that in the low level of stress, the percentage of subjects increased from 50.0\% in the pre-surgery to $71.4 \%$ in the post-surgery while the high level of stress decreased from $21.4 \%$ in the presurgery to $7.1 \%$ in the post-surgery. Moreover, the percentage of subjects who were in-between fell from $28.6 \%$ in the pre-surgery to $21.4 \%$ in the post-surgery. Thus, the situation after surgery decreased the stress level.

Figure 1 shows the stress variation in every stress level of the researched subjects in pre-surgery and postsurgery situations.
Figure 2 shows that the calculated average of the stress level of each subject was lower in post-surgery in $92.9 \%$ of cases.

We also found that the standard deviation of the responses of each subject after surgery was lower than in the pre-surgery in all cases. These results indicated a reduction of stress in the subjects after surgery confirming the data observed in Figure 1.

In post-surgery situation, the symptoms associated with the recognition of stress decreased in most of the subjects. We observed that there were no higher results in post-test situations with 04 results in equality and 28 with differences. The result with the greatest discrepancy was seen in the symptom number 14 , strained muscles, with difference of 05 points in improvement in the post-surgery (Figure 3).

\section{Discussion}

The obtained results showed reduced levels of stress after the labial palatine reconstruction surgery. According to Le Doux (2001), Koenigs et al. (2007), Lipp (1998) and Manly (2008), fear feeds anxiety, and the emotions, when unbalanced, can lead to increased levels of stress. On the other hand, the maintenance of stress can generate tables of psychological suffering. In the present study, after surgery, the subjects had the stressor condition reversed to the one in pre-testing, that is, reduced levels of stress. The primary emotions are reactions that can achieve some useful goals, necessary for survival. In pre-surgery contingencies the emotional reactions are tangential to the struggle for survival, where the basic levels of bodily conduits are highly activated and the sensation generated by emotion tends to remain for a period of time.

The anticipation of the caretakers regarding the unexpected was one of the emotional factors identified. The subjects of the study, caregivers or guardians of patients who had undergone multiple surgeries, were more stressed in the pre-surgery because of the procedures and care taken, they also went through several tests and, if the results were not within the standards of normality - such as the patient coming down with a cold or flu or any other type of disease - 
the surgery would be suspended for the patient's safety. The patient should return to the city of origin to undergo to a specific treatment and only after that return to the hospital, where he would be resubmitted to all the preparatory exams; if the results were satisfactory, the procedures for surgery would be carried out. By the time of confirmation of the surgery, the entire family is exposed to concerns and all the other anxiety conditions. The results of this study showed that the condition of the parents in this situation is highly stressful due to multifactorial aspects, such as the prior contingencies of the surgery, the patient's general health being in optimized conditions, and the effectiveness of the surgical procedure altogether.

Lofiego (1992) claims that the traumatic events are a result of external stimuli. The subjects in the presurgery situations were in expectation of test results proving normality for the surgical procedure. Once the surgery was confirmed, the environmental pressure decreased, and allowed parents/caregivers show themselves less anxious. However, the study showed that even after the scheduling of the surgery, the subjects presented varied stress levels.

Among the family members, there were ambivalent feelings from feeling satisfied, safe and quiet, up to feelings considered negative, such as agitation, anxiety, longing, wanting to cry or to give up the surgery, body aches, trembling, among others.

According to Moraes et al. (2009), the family members appreciate a hospital environment that favors the development of support during the phase preceding surgical procedures, such as expressive and recreational activities and their interaction with the child. This cozy environment can facilitate the adjustment of the child and family to the hospital context and the activities favor both of them, promoting the relief of anguish and anxiety.

Therefore, the surgical waiting can be a stressful event for parents, but when they have individual resources and adequate coping strategies from past experiences, complemented by a safe network of support, such elements are effective to deal with the stress of the situation.

The way parents/caregivers manage the stress 522 problems directly influences on the use of the resources provided in the hospital system. When they accept and participate in support and guidance groups, they create favorable contingencies in decreasing anxiety that reflect positively on the child (Coluchi, 2002; Troíjo, 2001).

The organism under stress builds symptoms, even when the eliciting situation changes, the immediate disappearance is not immediate, because the body needs time to reorganize itself. Affective and social relationships are inseparable and indispensable aspects for the organization of the body representations (Tavares, 2003). In the present study, the data showed loss in the perception of the body image. After surgical condition, the subjects showed greater perception about their own bodies and needs of improvement in self-care and health. In the study of self-image of the subject after surgery, we verified improvement. For Tavares (2003), the plasticity of the biologically complex structure sustains the individuality and the state of constant transformation of the human being. In that sense, the human being is led to view the body image as a complex phenomenon, which should be viewed from multiple perspectives, a constantly changing process that integrates multiple dimensions, vulnerable to internal and external dynamic processes that are linked all the time, recognizing, however, its unique and indivisible character. The dissociation is another manifestation present in stressful conditions. The subjects from the study had difficulties perceiving the bodies of support (feet, knees, thighs, hips) during the pre-surgery period. This condition was more present in the post-surgical situation.

Sympathetic activity can both promote vasodilation as vasoconstriction in arterioles that vascularize the skeletal muscle. The sympathetic nervous system optimizes blood flow to the organs, regulates body temperature and the intensity of metabolism, regulating also visceral activity. The activity of the parasympathetic nervous system reduces cardiac activity, facilitates digestion, increases the secretion of the lungs, the eyes and mouth, controls the convexity of the lens of the eye, constricts the pupils, controls bowel and bladder emptying and controls the erection of the sexual organs. Autonomic and neurophysiological manifestations necessary to the adjustment to 
situations of danger, identified by the autonomic nervous system have been reported by the participants of the study (Gazzaniga et al., 2006).

For the sample studied we observed that mothers are predominantly those who accompany their children in situations of surgery for reconstruction of cleft lip and palate. This data reflects the presence of the maternal bond and the practical and emotional availability, especially when in an instinctive situation of threat or danger. Moraes et al. (2009) argue that the capacity to establish the bond between mother and baby and moderate their pulsions is very important to strengthen the ego of the child.

The rehabilitation of people with cleft lip and palate lesions is a long process experienced by the patient and their family. The satisfactory adaptation results mainly from attitudes in relation to the fissure and the event of hospitalization for medical-surgical corrective procedures. Thus, the understanding of the family stress expands and resizes the responsibility of the professional teams in directing their efforts for an entire approach to the child with cleft lip and palate.

Therefore, the investigation of stressful conditions in caregivers, parents or guardians of children with cleft lip and palate, allowed us to substantiate the conclusions below:

I Subjects, parents or guardians of patients with cleft lip and palate in the surgical situation, showed higher levels of stress in the pre-surgery period;

II The comparison between the averages allowed us to identify that the responses of the subjects in the pre-surgery condition were higher than the average in the post-surgery condition with $95 \%$ of reliability level, that is, the stress level in the pre-surgery was greater than in the post-surgery;

III We found that in the pre-surgery condition, the stress levels were high, with changed quality on autonomic aspects of the body and unsatisfactory bodily responses.

\section{References}

Benevides-Pereira, A. M. T. (2002). Burnout: o processo de adoecer pelo trabalho. In A. M. T. Benevides-Pereira (Org.),
Burnout: quando o trabalho ameaça o bem-estar do trabalhador (pp.21-91). São Paulo: Casa do Psicólogo.

Carraro, M. M. (2001). Ansiedade traço-estado de pacientes pré-cirúrgicos: comparação entre pacientes com experiência prévia em uma ou mais cirurgias orofaciais (Monografia não-publicada). Programa de Pós-Graduação em Psicologia Clínica, Universidade de São Paulo.

Coluchi, M. M. R. (2002). Reações emocionais de pais e/ou acompanhantes no grupo de espera cirúrgica do HRAC (Monografia não-publicada). Estágio em Psicologia Clínica e Hospitalar, Universidade de São Paulo.

Le Doux, J. (2001). O cérebro emocional: os misteriosos alicerces da vida emocional. Rio de Janeiro: Objetiva.

Gazzaniga, M. S., Ivry, R. B., \&Mangun, G. R. (2006). Neurociência cognitiva: a biologia da mente. Porto Alegre: Artmed.

Koenigs, M., Young, L., Adolphs R., Tranel, D., Cushman, F., Hauser, M., et al. (2007). Damage to the prefrontal cortex increases utilitarian moral judgements. Nature, 446(7138), 908-911.

Lipp, M. N. (1998). Como enfrentar o stress (5ª ed.). São Paulo: Ícone.

Lofiego, J. L. (1992). Fissura lábio palatina: avaliação, diagnóstico e tratamento fonoaudiológico. Rio de Janeiro: Revinter.

Manly, J. J. (2008). Critical issues in cultural neuropsychology: Profit fromo diversity. Neuropsychology Review, 18(3), 179-183.

Moraes, M. C. A. F., Buffa M. J. M. B., \& Motti, T. F. G. (2009). As atividades expressivas e recreativas em crianças com fissura labiopalatina hospitalizadas: visão dos familiares. Revista Brasileira de Educação Especial, 15(3), 453-470.

Motta, R. C. (2003). A avaliação da imagem corporal durante o processo do Rolfing (Dissertação de mestrado não-publicada). Programa de Pós-Graduação em Educação Física, Universidade Estadual de Campinas.

Pereira, F. R. N. (1999). Recursos utilizáveis pela família com criança portadora de deficiência auditiva (Monografia não-publicada). Programa de Pós-Graduação em Psicologia Clínica, Universidade de São Paulo.

Ribeiro, R. M., Tavano, L. D., \& Neme, C. M. B. (2002). Intervenções psicológicas nos períodos pré e pós operatório com pacientes submetidos a cirurgia de enxerto ósseo. Estudos de Psicologia (Campinas), 19(3), 67-76. doi: 10.1590/S0103-166X2002000300007.

Ruiz, E. A. C. (2007). Modelo de atendimento psicológico às famílias de crianças com fissura labiopalatina, na situação de cirurgia reparadora (Monografia não-publicada). Programa de Pós-Graduação em Psicologia Clínica e Hospitalar, Universidade de São Paulo.

Salina, C. S. A. (1999). Modos de enfrentamento de mães de crianças portadoras de fissuras lábio-palatais submetidas a cirurgias reparadoras (Monografia não-publicada). Programa de Pós-Graduação em Psicologia, Universidade de São Paulo.

Silva, R. F. M. A. (2003). Percepções de pacientes e acompanhantes no pré-anestésico de um hospital especializado: 
um estudo prático explorando a rotina diária (Monografia não-publicada). Programa de Pós-Graduação em Psicologia Clínica e Hospitalar, Universidade de São Paulo.

Silva Filho, O. G., Valladares Neto, J., Capelozza Filho, L., \& Freitas, J. A. (2003). Influence of lip repair on craniofacial morphology of patients with complete bilateral cleft lip and palate. Cleft Palate-Craniofacial Journal, 40(2), 144-133.

Spina, V. Psillakis, J. M., \& Lapa, F. S. (1972). Classificação das fissuras lábio-palatinas: sugestão de modificação. Revista do Hospital das Clínicas, 27, 5-6.
Tavares, M. C. G. C. F. (2003). Imagem corporal: conceito e desenvolvimento. Barueri: Manole.

Troíjo, M. A. F. (2001). Enfrentamento de pais e mães de pacientes portadores de fissura lábio palatal, durante a espera da cirurgia de Enxerto Ósseo Alveolar Secundário (EOAS) (Monografia não-publicada). Programa de Pós-Graduação em Psicologia Clínica, Universidade de São Paulo.

Received on: 24/5/2011

Final version on: 10/10/2011

Approved on: 17/11/2011 